\title{
Serum or Plasma
}

National Cancer Institute

\section{Source}

National Cancer Institute. Serum or Plasma. NCI Thesaurus. Code C105706.

The non-cellular portion of the circulating blood, with or without the clotting proteins present. 